\title{
Article
}

\section{More than sense of place? Exploring the emotional dimension of rural tourism experiences}

Jepson, Deborah and Sharpley, Richard A J

Available at http://clok.uclan.ac.uk/12826/

Jepson, Deborah and Sharpley, Richard A J ORCID: 0000-0002-2135-3206

(2014) More than sense of place? Exploring the emotional dimension of rural tourism experiences. Journal of Sustainable Tourism, $23(8+9)$. pp. 11571178. ISSN 0966-9582

It is advisable to refer to the publisher's version if you intend to cite from the work. http://dx.doi.org/10.1080/09669582.2014.953543

For more information about UCLan's research in this area go to http://www.uclan.ac.uk/researchgroups/ and search for <name of research Group>.

For information about Research generally at UCLan please go to http://www.uclan.ac.uk/research/

All outputs in CLoK are protected by Intellectual Property Rights law, including Copyright law. Copyright, IPR and Moral Rights for the works on this site are retained by the individual authors and/or other copyright owners. Terms and conditions for use of this material are defined in the policies page.

\section{CLoK}

Central Lancashire online Knowledge www.clok.uclan.ac.uk

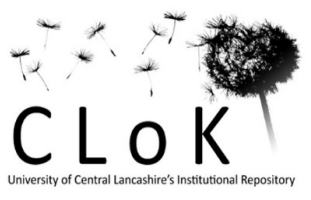




\title{
More than sense of place? Exploring the emotional dimension of rural tourism experiences
}

\author{
Deborah Jepson and Richard Sharpley
}

\begin{abstract}
It is widely suggested that participation in rural tourism is underpinned by a sense of rural place or 'rurality'. However, although nature and the countryside have long been recognised as a source of spiritual or emotional fulfilment, few have explored the extent to which tourism, itself often claimed to be a sacred experience, offers an emotional / spiritual dimension in the rural context. This paper addresses that literature gap. Using in-depth interviews with rural tourists in the English Lake District, it explores the extent to which, within respondents' individual understanding of spirituality, a relationship exists between sense of place and deeper, emotional experiences and, especially, whether participation in rural tourism may induce spiritual or emotional responses. The research revealed that all respondents felt a strong attachment to the Lake District; similarly, and irrespective of their openness to spirituality, engaging in rural tourism activities resulted in highly emotive experiences for all respondents, the description / interpretation of such experiences being determined by individual 'beliefs'. However, sense of place was not a prerequisite to emotional or spiritual experiences. Being in and engaging with the landscape - effectively becoming part of it - especially through physical activity is fundamental to emotional responses.
\end{abstract}

Key words: Rural tourism; rurality; sense of place; emotional experience; spirituality 


\section{Introduction}

Rural tourism is a diverse activity. Occurring in both natural and built rural environments, it takes numerous forms and, as a consequence, the reasons or motivations for participating in rural tourism are equally numerous. For many, the countryside is undoubtedly a place to pursue recreational activities that involve engaging with the outdoors and interacting with the natural environment (Kastenholz \& Lima, 2011); for others, it is the opportunity to follow other interests and activities, whether directly or indirectly related to the rural context. Indeed, the motivations for tourism more generally, such as relaxation, escapism or 'egoenhancement' (Dann, 1977), are of equal relevance to participation in rural tourism in particular (Cain, 2013), hence the difficulty in defining precisely rural tourism or the rural tourist as distinct from other manifestations of tourism (Lane, 1994; Roberts \& Hall, 2001; Sharpley, 2007).

However, despite this broad scope of rural tourism with respect to touristic opportunities and practices, it has long been recognised that the fundamental attraction of the countryside as a tourist destination lies in what is often referred to as a sense of rurality (Aitchison, MacLeod \& Shaw, 2000; Cloke, 2006; Halfacree, 1993; Horton, 2008; Woods, 2011). In other words, tourists are drawn to the countryside not only by its physical attributes and intrinsic qualities, such as open space, fresh air or peace and quiet; they are also attracted by what the countryside represents. Indeed, since the European Romantic Movement ${ }^{\mathrm{i}}$ of the early nineteenth century first elevated the status of the countryside as a site for leisure and recreation, establishing it as the antithesis to modern, industrialised and primarily urban society (Lane, 2009), aesthetically and culturally driven shifts in values have continued to transform the rural from 'desolate and culturally empty spaces' into 'desirable culturally laden places’ (Darby, 2000, p. 54; also Harrison, 1991). Specifically, the countryside has been socially constructed as a significant though idyllic or imagined (Short, 1991) place representative of restful landscapes, an unhurried, traditional rhythm to life, a romanticised pre-industrial era of innocence (Bunce, 1994; Cloke \& Little, 1997; Little \& Austin, 1996). In short, the countryside has come to represent, as a setting for tourism, a 'green and pleasant land' (Newby, 1985). Consequently, the demand for rural tourism is seen to be defined by a combination of three factors: the countryside's tangible attributes, the manner in which tourists interact with those attributes and the cultural meaning or significance of the countryside, or by what is commonly and collectively referred to as a sense of (rural) place (Greider \& Garkovich, 1994; Manzo, 2003, 2005). 
At the same time, it is not surprising that, reflecting the cultural transformation of the countryside in particular from a place of production to one of symbolic consumption, nature more generally became significant for its aesthetic qualities. Not only did the 'naturalness' of nature, as espoused by the Romantics, contrast with the 'unnaturalness' of urban centres; it also came to be seen as epitomising goodness and purity (Burchardt, 2002) and, as a consequence, was viewed as the 'antidote to the supposed vices of the working people' (Burchardt, 2002, p. 47). Thus, nature represented an escape from the ugliness of the industrialised cities to spaces for reverie, self-contemplation and emotional refreshment (Barsham \& Hitchcock, 2013; Seaton, 2013). As Harrison (1991, p. 21) notes, 'the educated and cultured... began to view the countryside as a source of spiritual renewal', establishing the foundation for contemporary secular spirituality being manifested in 'soul stirring encounters with nature', exemplified by feelings of 'wonder, awe, wholeness, harmony, ecstasy, transcendence and solitude’ (Timothy, 2013, p. 38). Moreover, according to Timothy (2013), the current increasing demand for touristic encounters with the natural environment reflects a continuing search for solace and communion with nature driven by the conspicuous contrast between the unnaturalness of the city and the simplicity of nature.

What is surprising, therefore, is that few if any attempts have been made to explore empirically the extent to which rural tourism is motivated by, or offers the opportunity for, spiritual or transcendental experiences. Indeed, as noted elsewhere (Jepson \& Sharpley, 2011), it has long been argued that tourism more generally is 'functionally and symbolically equivalent to other institutions that humans use to embellish and add meaning to their lives' (Graburn, 1989, p. 22), a sacred journey or, as Allcock (1998) puts it, 'a secular substitute for organised religion'. In other words, it is suggested that tourism may be considered either a regular secular ritual that acts as a counterpoint to everyday life and work (the annual vacation), as a personal transition or rite of passage at particular junctions in an individual's life (Nash, 1996) or, more generally, as a source of spiritual meaning or emotional wellbeing. However, this spiritual / emotional role of tourism been subjected to only limited empirical scrutiny, particularly in the rural context.

This paper addresses this notable gap in the literature. Specifically, it considers the outcomes of research which explores the extent to which tourists to the English Lake District are motivated by or experience emotional or spiritual fulfilment through their visits. In other words, the research seeks to identify if rural tourists engage with rural places at a deeper, 
emotional / spiritual level. In so doing, it not only builds on an earlier study by the authors which revealed that, (at a conscious level at least), rural tourists primarily appear to associate their experiences with a constructed sense of place, and called for more in-depth research into individuals' perhaps subconscious experiences of the countryside. It also contributes an additional dimension to the understanding of both rural tourism in particular and of the spiritual dimension of tourism more generally. The first task, then, is to review briefly the concept of rural sense of place and the significance of spirituality in contemporary society as a framework for the subsequent research.

\section{Rural tourism and rural place}

'To exist at all...is to have a place - to be implaced...To 'be' is to be in place..." (Casey, 1993, p. 13). Place is an essential marker of human existence and people make sense of their existence through their emotive or affective relationships with place. Similarly, in the specific context of tourism, the tourist's relationship to place is fundamental to the tourist experience. That is, the destination may be the objective of the tourist, but place is the subjective reason for the journey. Thus, tourism cannot be understood only in terms of geographic loci; it is also necessary to understand the social, cultural and psychological interactions that visitors have with the place (Morgan, 2009). But, what is 'place’?

Place has throughout history been the focus of philosophical enquiry (Cresswell, 2004), although contemporary academic concern with place is commonly associated with developments in human geography, in particular the pioneering work of Relph (1976) and Tuan $(1974,1977)$. Since then, not only has place and, in particular, the emotional significance of place, been considered from a variety of disciplinary perspectives but also a variety of terms have been proposed to describe the emotive relationships between people and place, including place bonding, place identity and place attachment, although 'sense of place' is widely accepted as a legitimate umbrella term (Jorgensen \& Stedman, 2001: Kyle \& Chick, 2007). Irrespective of the terminology, however, fundamental to the place discourse is the distinction between space and place; what distinguishes space from place is the meaningless to the meaningful or 'the particularity of place to the homogeneity of space' (Bremer, 2006, p. 26). In other words, an undifferentiated space only becomes a place 'when we endow it with value' (Tuan, 1977, p. 6) or, as Gieryn (2000, p. 465) alternatively states, 'place would revert to space if we vacuumed out the distinct collection of values, meanings 
and objects that created it'. Thus, sense of place, of a belonging or attachment to a particular place, results from the meanings or significance that people attach to that place and the ways in which they interpret it.

The question then to be addressed is: what factors determine these meanings and interpretations? On the one hand, the meanings that people or groups ascribe to particular places may be rooted in ‘shared cultural understandings of the terrain' (Gieryn, 2000, p. 473) and, consequently, 'a particular physical place or landscape may embody multiple landscapes, each of which is grounded in the cultural definitions of those who encounter that place' (Greider \& Garkovich, 1994, p. 2). On the other hand, people make conscious choices according to their particular desires and needs with respect to how they select and use places (Manzo, 2003). That is, the meaning that people attach to a particular place will be revealed through the ways in which they interact with it. Thus, in addition to its basic element, that is, the physical or objective environment, place comprises two further components, namely, the socially constructed meanings of place and people's experience of or behaviour within place.

In the context of this paper, this suggests that the significance of rural places, or the sense of place that tourists (and, indeed, inhabitants) experience in rural areas, emanates from these three components. Certainly, the physical attributes of rural places, both tangible and intrinsic, determine their attraction to tourists; the more attractive the landscape and/ or the more opportunities for engaging in leisure pursuits in that landscape, the more 'at home' people may feel there. Additionally, however, meaning will be ascribed by how people experience a place, either in the past or present. Childhood memories of family holidays, for example, or the solitude of walking alone in the countryside may contribute to a sense of belongingness whilst more generally, 'place social bonding' (Ramkissoon, Weiler \& Smith, 2012, p. 264) is increasingly seen as a powerful agent of place attachment. That is, attachment to a particular place may evolve from the communal bonds developed between people in that place (Hammit, Backlund \& Bixler, 2006). Equally, the socially-constructed meaning of the countryside, or the rurality referred to earlier, also provides a cultural framework within which tourists may develop a sense of rural place. Certainly, research reveals that responses to or interpretations of the experience of particular places, such as the countryside, may similarly be socially constructed, manifested in clichéd descriptions of place and experience (Sharpley \& Jepson, 2011). 
Inevitably, the three components of place remain contested with respect to their relative significance. Stedman (2003), for example, argues that the contribution of the physical environment to a sense of place remains underestimated. Nevertheless, there is general consensus that not only do they collectively underpin sense of place in general but also that sense of place is a key factor in the demand for rural tourism in particular. However, the meaning of the countryside may also be defined by its potential role in spiritual fulfilment. That is, reflecting the sacralisation of nature in the early nineteenth century, de Botton (2003, p. 171) observes that 'It is no coincidence that the Western attraction to sublime landscapes developed at precisely the moment when traditional beliefs in God began to wane. . . The landscape offered [travellers] an emotional connection to a greater power'. In other words, de Botton (2003) suggests that not only did the advent of industrialisation / urbanisation herald the beginning of the secularisation of society (a process that allegedly continues to this day) but that certain landscapes (or rural places) became endowed with a sacred meaning that compensated for the increasing spiritual void in urban society. Indeed, as the following section now considers, contemporary society may be defined by increasing secularisation and a consequential search for spiritual fulfilment beyond the confines of traditional religious institutions and practices (Heelas \& Woodhead, 2005; Stark, Hamberg, \& Miller, 2005), a search that might be satisfied through rural tourism experiences.

\section{Tourism and the search for spirituality}

Underpinning the claim that contemporary tourism is a sacred journey or pilgrimage (Graburn, 1989; Timothy \& Olsen, 2006) is the suggestion that modern society is becoming increasing secular. Moreover, it is claimed that this secularisation is evidenced by the rejection of traditional religious institutions and practices and, in particular, the decline of the church (Pargament, 1999; Lambert, 2004; Houtman \& Aupers, 2007), an institution that historically demanded moral and social responsibility of the community and in return offered stability, cohesion and spiritual guidance to its followers (Wuthnow, 1998; Heelas \& Woodhead, 2005). This alleged post-modern decline in traditional religion and the commensurate secularisation of society has meant that Western civilisation has been set adrift with no moral compass, no sense of belonging or support (Houtman \& Aupers, 2007). Without the church and traditional religious ritual as the cornerstone of society and with a lack of strong community/family structure, individuals have become 'disconnected'; a 
religious/spiritual void has opened up that has triggered a complex quest to find spiritual satisfaction through other means (Wuthnow, 1998).

However, although religious conviction and involvement may have weakened, in its place there is evidence of an escalating desire by society to sustain and nurture spiritual health (Heelas \& Woodhead, 2005). According to Wuthnow (1998, p. 138), the last half of the twentieth century witnessed a major shift in religious practices manifested in the 'traditional spirituality of inhabiting sacred places giving way to a new spirituality of seeking'. For example, recent research has found that, in Britain at least, 'it is clear that spiritual beliefs are not the preserve of the religious... a majority of non-religious people hold spiritual beliefs. This is particularly evident when it comes to non-traditional forms of religious beliefs, where it seems to make very little difference whether someone considers themselves religious or not' (Theos, 2013, p. 25). In contrast to religion that is fixed in timebound rituals, sacred sites of worship and communal responsibility, contemporary secular spirituality offers the freedom to choose one's own path of faith without the condemnation and constraints exerted by ecclesiastical mandates. The general acceptance of both traditional and alternative religious beliefs has allowed people to have spiritual experiences without religious faith. Timothy and Olsen (2006:4) note that many people who consider themselves as spiritual would not view themselves as religious and vice versa. Spirituality has become a 'dynamic process' (Pargament, 1999:4), with individuals seeking to define their own private faith and adopting a patchwork quilt or bricolage of flexible beliefs and practices (de Vries, 2008; Wuthnow, 1998).

As considered later in this paper, there is no consensus over the definition of spirituality. Indeed, in the Oxford English Dictionary, spirituality is defined broadly as 'The quality or condition of being spiritual; attachment to or regard for things of the spirit as opposed to material or worldly interests', whilst the adjective 'spiritual' is ambiguously defined as 'Of or relating to, affecting or concerning, the spirit or higher moral qualities, especially as regarded in a religious aspect' (OED, 2014). However, two points should be emphasised. On the one hand, contemporary spirituality appears to be located in a quest for personal identity, a journey to find one’s inner-self (de Vulpian, 2008; Teasedale, 1999). This search for spiritual nourishment is believed by some to be 'central to human social psychology' (Haq \& Jackson, 2006, p. 1), and is reflected in increasing participation in spiritually enhancing activities, such as spiritual pilgrimages, health and well-being courses, or holistic programs for the mind, body and spirit, such as yoga and tai chi practice, all of 
which offer the opportunity to improve the spiritual self and raise spiritual consciousness. In particular, and of relevance to this paper, it is widely claimed that the search for spiritual fulfilment and transcendence is sought through touristic pursuits (Laing \& Crouch, 2009; Little \& Schmidt, 2006).

On the other hand, however, the concept of spirituality itself may be considered from alternative perspectives which, collectively, endow it with a more complex meaning. That is, the preceding discussion on the emergence and contemporary significance of spirituality, placing it in opposition to traditional religious practice yet with an emphasis on 'faith' in a broader sense, is implicitly located within a theological framework. However, a humanistic perspective on spirituality establishes a relationship between the individual not only with the subjective but with the material (Elkins, Hedstrom, Hughes, Leaf and Saunders, 1988). For example, Mason (2000) cites the Dalai Lama’s definition of spirituality as being 'concerned with those qualities of the human spirit - such as love and compassion, patience, tolerance, forgiveness, contentment, a sense of responsibility, a sense of harmony - which bring happiness to both self and others'; that is, human qualities which Mason considers to be 'moral and emotional' rather than spiritual. More specifically, Fisher, Francis and Johnson (2000: 135) identify four domains within which harmonious relationships are necessary for the achievement of spiritual well-being:

i. The personal domain, with a focus on the self (meaning, purpose and values in life), creating self-awareness, identity and esteem

ii. The communal domain, focusing on interpersonal relationships between the self and others based on morality and culture.

iii. The environmental domain, with a concern for caring and nurturing the natural environment drawing on a sense of awe, wonder and connectedness with the environment.

iv. The transcendental domain, focusing on a relationship between the self and ‘some-thing or some-One beyond the human level’ (Fisher et al 2000: 135).

Importantly, Fisher et al. (2000) suggest that although all four domains are considered fundamental to spiritual health, individuals typically prioritise one domain over the others. In other words, well-being is individually determined and perceived according to personal characteristics and values and, thus, may be more generally considered an emotional response 
to harmonious relationships in one or more of the above domains that, only in particular circumstances, may be defined as transcendental or spiritual in a traditional theological sense. Environmentalists, for example, possess 'at least, a sense of awe and wonder about the environment. They go beyond responsible management of the physical, eco-political, and social aspects of the environment to a sense of connectedness of the individual or group with it' (Fisher et al. 2000: 136). However, the extent to which their spiritual as opposed to emotional well-being is enhanced remains debateable.

This complexity of concept of spirituality is significant in the context of this paper. That is, spirituality and travel have intersected throughout time and the roots of modern tourism can be traced back to early pilgrimages and other religiously motivated journeys (Digance, 2006; Timothy \& Olsen, 2006). Moreover, contemporary tourism is widely considered to be a secular pilgrimage, a means of compensating for the religious /spiritual void in modern societies. However, as already observed, few if any attempts have been made to test empirically the relationship between tourism and spirituality This is not to say that the potential spiritual benefits of experiencing specific (natural) places, such as wilderness, forests and the coastal fringe have not been explored (Bull, 2006; Fredrickson \& Anderson, 1999; Heintzman, 2007). Moreover, the relationship between well-being more generally and nature has also long attracted increasing academic attention (Burls, 2007; Darker, Larkin \& French, 2007; Driver, Dustin, Baltic, Elsner \& Peterson, 1996; Kaplan, 1995; Korpela \& Hartig, 1996; Montes, 1996), the outdoors being recognised as a source of self-renewal, mental well-being and stress management. However, few if any attempts have been made to determine the extent to which rural tourism in particular offers a spiritual dimension or experience, or indeed whether that experience is better defined as emotional rather than spiritual. That is, the consumption of rural tourism experiences is typically related to the tangible characteristics of the countryside, albeit within the framework of a constructed rurality (Roberts \& Hall, 2001). The understanding of the spiritual / emotional meaning of those experiences to the individual tourist, however, and the extent to which they may transcend a culturally-defined sense of (rural) place, remains limited. This research addresses that lack of understanding.

\section{The Research: tourism and spirituality in the Lake District}


The research was undertaken amongst tourists visiting and engaging in active (as opposed to more passive, 'urban') pursuits in the Lake District, a rural region in north-west England that has not only long been a popular rural tourism destination but that also offers a cultural landscape endowed with an image that 'communicate[s] a sense of something especially alluring and enthralling, capable of conferring mental and spiritual as well as physical benefits upon the discerning visitor' (O’Neill \& Walton, 2004, p. 20). One of England's ten national parks and covering an area of c.880 square miles, the Lake District has long been renowned for its unique natural landscape of lakes and mountains augmented by centuries of human activity (Denyer 2013); its fells, valleys, lakes, towns and villages nowadays attract some 15 to 20 million day visits annually.

\section{Methodology}

For the purposes of this study, unstructured in-depth interviews with a purposefully selected sample of respondents was adopted as the most appropriate methodology. As Weinberg (2002) notes, the interactive nature of interviewing encourages specific, focused forms of conversation which allow respondents to express their own viewpoints with respect to a particular social phenomenon that might not otherwise be revealed. In particular, the inherent fluidity of unstructured interviews enables the researcher to follow specific lines of enquiry based on the interviewee's responses, thereby endowing the data with greater depth and detail and eliciting 'an authentic account of the interviewee’s subjective experience' (Klenke, 2008, p.125). Conversely, the diverse outcomes of unstructured interviews may limit the opportunity to draw comparisons between the responses of different interviewees whilst interviewer bias may be considered inevitable. Nevertheless, it was considered that unstructured interviews would most effectively meet the objectives of this research.

Twelve respondents (five female and seven male, aged between thirty and seventyfive), all regular visitors to the Lake District engaging in active pursuits in the landscape, were purposefully selected from a larger group of thirty-one people who had contributed to focus group discussions in an earlier related study. Importantly, they were selected not only on the basis of their expressed willingness to participate in the interviews, but also according to their self-categorisation of being religious, spiritual or non-religious / spiritual. In other words, it was evident from the earlier study that people considered themselves to be religious and / or spiritual to varying extents and, therefore, interview respondents were purposefully 
selected to reflect contrasting viewpoints, ideologies and world views in this context. Of the twelve, seven considered themselves to be 'spiritual' (that is, they experienced or sought a spiritual dimension to their lives), two held strong religious/spiritual affiliations (defined by regular church attendance and a stated belief in God), one was unsure or was unwilling to refer to emotional feelings as spiritual, whilst the remaining two considered themselves to be non-religious/non-spiritual.

The interviews, administered by the first author, took place in respondents' homes, lasted between 60 and 90 minutes and were digitally recorded. The discussions covered a variety of themes relevant to the fundamental aims of the research, including: understandings of and views on spirituality; distinctions between emotive and spiritual experiences; the significance of the both the physical environment and the active use of that environment to the rural tourism experience; respondents' perceptions of significant characteristics of the Lake District as a basis for indentifying their sense of place; and, respondents' emotional / spiritual responses to the Lake District. Subsequently, the interviews were transcribed and analysed in order to identify key themes relevant to the research objectives. Initial data analysis was undertaken through the use of a qualitative data analysis program (NVivo) which facilitated the categorisation of data into nodes and sub-classifications (trees). Patterns were identified and data categories merged into key themes which were coded under a smaller number of headings. However, given the richness of the data, further manual analysis was deemed necessary to reveal fully the respondents’ subjective experiences.

Deconstruction of the data through 'phenomenological reduction' (Patton, 2000) produced data clusters around emergent themes, permitting the formulation of an analysis grid to isolate relevant perceptions and viewpoints.

\section{Research outcomes}

As noted above, purposeful sampling for the interviews was undertaken based on respondents' self-categorisation with respect to their religious or spiritual beliefs and practices. It should be noted, however, that people inevitably understand or interpret their spiritual or emotive feelings and experiences in different, very personal ways (Ashley, 2007; (Flanagan and Jupp, 2007). Moreover, the nature of human experience as a series of interconnected events that cannot be clearly separated from each other is such that it is difficult to isolate or identify specific factors that, in the context of this study, may influence 
the spirituality or otherwise of rural tourism experiences. Thus, the interviews initially sought to identify the significance of spirituality to the respondents and their understanding of the concept as a basis for considering their emotive relationship with and touristic experience of the Lake District.

Not surprisingly, perhaps, no consistency emerged from the interviews with respect to respondents' interpretation, definition or experience of spirituality, reflecting the welldocumented complexity and nebulousness of the concept referred to earlier in this paper (Zinnbauer et al., 1997). Typically, respondents found it difficult to express meanings of spirituality and to isolate spiritual moments or experience, resorting instead to defining their spirituality in terms of past and current influences in their lives, influences that have shaped their understanding of their lived experiences and determined their personal spiritual pathways. Nevertheless, those respondents in the 'spiritual' group frequently referenced spirituality against religion. For example:

Religion is kind of mechanistic or it can be mechanistic. Spirituality is something that is much more innate and free flowing. I think they are quite different things... Spirituality is separate from religion, very much so! In fact I think that organised religion hijacks peoples' spirituality.

Conversely, those from the 'religious' group either associated spirituality with religion - to be religious is to be inherently spiritual - or viewed spirituality as separate from religion. At the same time, respondents applied differing contextual interpretations of spirituality. For one respondent, spirituality is very much to do with a sense of myself, how comfortable I feel with myself and how accepting I am of myself. For another, my own spirituality...makes me explicitly conscious of morals and morality.

As might be expected, the 'non-spiritual' respondents either could not identify with the concept of spirituality: I don't know whether you call it spiritual or not but...[in the hills].. you definitely get a feeling of well-being or specifically denied it: 
My view is that...religion and spirituality...come out of peoples' fear. I guess I am not a spiritual person...for me that is just what I call an emotional experience... as far as spiritual experiences go I don't relate to it at all.

Thus, from the research there emerged in effect a continuum of spiritual interpretation / beliefs amongst the respondents, from those with strong religious / spiritual convictions to those with equally strong 'non-spiritual' beliefs, interspersed by those with varying degrees of certainty about their understanding and acceptance of spirituality. Significantly, however, many respondents across this spectrum suggested that, when considering spirituality as a concept, emotional engagement with the countryside was a significant element of their experience. That is, for those respondents who recognised spirituality, emotional openness and an intensity of emotions underpinned their spiritual experiences; for those who did not acknowledge spirituality, the terminology used to describe their powerful emotional feelings was not dissimilar to phrases described as spiritual by those who acknowledge their spirituality. For example:

Sometimes just sitting there with great views down a valley and thinking to myself that I am part of something but I am only a small part of something that is really big of an area that has so much power...

In other words, the research suggested that those who rejected the notion of spirituality nevertheless experienced powerful emotive feelings akin to spiritual experiences, whilst the situations in which these feelings occurred were almost identical for non-spiritual and spiritual respondents. Thus, it became clear that, for many respondents, the distinction between emotional and spiritual experiences was not always clear, reflecting the argument of some that spirituality is simply an emotional phenomenon (Flanagan and Jupp, 2007). The implications of this are considered later but, against this background, the interviews then turned to the respondents' emotional responses to their touristic experiences of the Lake District. Key themes / sub-themes are summarised in Table 1 and discussed in detail below. 
Table 1: The research: key thematic outcomes

\begin{tabular}{ll}
\hline Theme & Sub-theme \\
\hline Countryside: tangible and intangible elements & Rural vs. urban \\
& The physical environment \\
& Weather and light conditions \\
& Nature \\
& Silence and solitude \\
\hline Physical activity & \\
\hline Sense of place: the Lake District & Place \\
& Person \\
\hline
\end{tabular}

\section{Countryside: tangible and intangible elements}

As noted in the introduction to this paper, the significance of the countryside as a place for tourism is framed by a socially constructed rurality which endows it with a collective understanding (Aitchison et al., 2000). Nevertheless, through individual experiences, personal constructions of the countryside are reshaped and redefined. In this study, all respondents were primarily motivated by the opportunity to engage actively with the Lake District landscape, yet a number of factors emerged from the interviews that augmented their touristic experience with an emotional dimension.

i.Rural vs. urban. As might be expected, visiting the Lake District offered the majority of respondents both physical and, importantly, emotional escape from their home towns and normal life:

You know you are away from work. You know you are away from your troubles...escapism really...you are away from the hustle and bustle as well... 
Countryside... a kind of a de-stressor or where bits of the mental jigsaw kind of fall into place when I am out and about.

In other words, it was clearly evident that the slower pace of life away from urban areas was emotionally significant to the respondents. At the same time, however, it was also evident that the physical environment, as one of the constituent elements of 'place', was also referred to by many respondents as fundamental to their experience, particularly at an emotional level.

\section{ii.The physical environment.}

The physical environment often plays an important part in emotional engagement and attachment to place (Stedman, 2003). In particular, the countryside offers a physical environment related to sense of space, greenness, hills, mountains, lakes, marshes, moors, forests, fens and any number of attributes commonly associated with rural spaces. These may include farms, villages, churches, barns and other human-made objects representative of countryside settings. The landscape of the countryside is a powerful enticement for tourists, whether purely to gaze upon or to physically interact with the environment. The interview respondents, all of whom had visited numerous rural places in Britain and abroad, referred to a number of conceptually similar attributes when referring to the tangible qualities of the countryside, such as: scenery, landscape, outdoors, nature and physical environment. Although often used interchangeably, these terms differ in meaning, intent and usage. In particular, landscape embraces the idea of a picture, a snapshot of a particular view inclusive of natural elements, such as mountains or streams, built structures and transient elements related to weather and light (Darby, 2000); it suggests a scene from nature that has been appropriated and framed by the agency of human perspective' (Aichison et al., 2000, p. 72). Scenery, conversely, gives character to the landscape. Both, however, imply a visual quality, whereby the observer gazes rather than interacts with the environment.

The respondents indicated that they gained positive emotional experiences from looking upon the scenic qualities of the landscape; however, actively engaging with the landscape added a different quality to their emotional experience. For some, physical engagement was more significant than simply gazing on scenery whilst, for others, enjoying the scenery was the dominant factor. For most participants, however, some combination of 
the two was required for more intense emotional experiences, active engagement with the physical environment, in effect becoming part of the landscape, being a key factor in the complex affective and cognitive process of place experience. Indeed, although the quality of countryside views was a specific element of the physical environment cited by all respondents, it was generally agreed that mountains or hills offered the best views whilst, in particular, it was the view from the top of mountains or hills that elicited more powerful emotions amongst respondents. In other words, it was the physical effort of climbing combined with the reward of the view from the top that elicited emotive responses:

I sit there and I am in awe of the surroundings and feel that I am just one person who is so insignificant in comparison to my surroundings. When I look down a ridge and the power of the land, the rock, the formation...I am just in awe.

For some respondents, the experience was explicitly spiritual:

It refreshed my soul! All I can say is that when I am out in the mountains (walking) I can look at the wonder of it and I can say that there is more to life than this. There is a creator out there who has created this.

For me personally...my spirituality...is connected to the mountains.

The relevance of active engagement with the physical environment is returned to later in the paper but a number of other specific themes, considered below, also emerged from the discussions with respondents.

iii. Weather and light conditions. Although weather and light conditions contribute to the visual quality of the countryside, experiencing particular weather conditions was, for many respondents, a contributory factor in emotional experiences: 
In a bizarre way I enjoy the weather changing so much... it brings you back down to earth sometimes and makes you realise that there are greater things out there...nature and it is a lot greater than mankind

iv. Nature. The restorative effects of the experience nature have long been recognised (Arnould \& Price 1993). More specifically, research has demonstrated that encounters with nature give rise to feelings and emotions most commonly linked to spirituality, such as awe, inspiration, reverence, connectedness, timelessness and reflection on personal meanings (Crystal \& Harris, 1997; Fredrickson \& Kerr, 1997) whilst, according to Mannell (1996), altered states of consciousness, such as flow and peak experiences, are typical human experiences of nature. Inevitably, therefore, nature and the outdoors rated very highly in respondents' emotional and spiritual experience, reference being made to the importance of nature not only to their touristic experiences but, in many cases, to their overall well-being:

My emotional well-being is more to do with being outside and in nature. I love going to castles and abbeys...but I get a much nicer and more contented feeling from just being outside.

Reference was also made to deeper spiritual feelings associated with nature:

Spirituality... whatever it is it is more than just this material existence and you do get in touch with it out in nature. I think when you are out in nature you are probably doing what humans beings were meant to do.

For many respondents, experiencing nature represented a return to a simpler existence, where the superficial layers of contemporary society are stripped back to reveal an instinctive unity with the natural world. This, in turn, acted as a catalyst for explicit spiritual experiences: 
In the outdoors and natural environment...I definitely feel closer to God there than I do in a church. At the end of the day you can do away with everything and as long as you have nature you can survive.

I certainly actively seek out natural rather than man-made environments. I do find that emotionally and spiritually these environments do help me and my mental health improves as a result of being immersed in such places.

Nevertheless, from the interviews it became evident that actively engaging with the physical environment again enhanced the emotional experience; that is, respondents' communion with nature was emotionally more powerful when being physically active in particular places.

v.Silence / solitude. According to Bunce (1994), the rural idyll is represented not only through landscapes but also soundscapes, often referred to in terms of tranquillity, quiet or peace. Certainly, for the interview respondents, silence predisposed them to emotional or spiritual experiences:

When you get to a place that you can listen to silence...because I think that is totally missing from our modern lives...silence. No human sounds...no wind either...you can hear the insects, the sheep bleating and the skylarks...the sounds of nature. It's very therapeutic.

It was the quietness. It was so quiet... I could have just stayed up there. It was so awesome.

However, more significant to the respondents was the opportunity to enjoy solitude; indeed, this was a theme raised by all interviewees, identifying it not only as an essential element of the rural experience but fundamental to their lives more generally. A number of different 
terms were used to express the condition of solitude, though in different contexts. For example, 'solitude' was referred to ambiguously by some respondents as they claimed to enjoy moments of self-reflection and contemplation even in group situations. In contrast, 'alone time’ was used explicitly to describe time on one’s own, an opportunity to think or 'be' uninterrupted by others, whilst 'getting away' was a commonly used phrase indicating the desire to be removed from large numbers of people, perhaps enjoying communal solitude - or communitas - with a group:

I don't really want to go to all the places everybody else is. I know I go with quite a big group...but they are like-minded people and we don't all crowd together. We go places some people will never have seen...the people that lead us know these places and we can walk all day and hardly ever see a soul.

Irrespective of the terminology used, however, respondents perceived solitude to be a vital part of the total experience, reflecting the findings of previous studies that have revealed silence / solitude to be conducive to emotional well-being or spirituality (Coble, Selin \& Erickson, 2003; Stringer \& McAvoy, 1992; Swatton \& Potter, 1998). Moreover, the physical environment combined with physical activity and solitude defined the emotiveness of their experiences. Indeed, reflecting Roberts' (1996, p. 71) assertion that 'the need to remove ourselves from the familiar, the predictable, the human, in order to hear the voice of the spirit is perhaps the most well-documented use of nature for spiritual encounter', many respondents indicated that, for them, solitude encourages a state of mind conducive for possible spiritual experience. For example:

I like going to the more wild, quiet places, away from other people because the further you are from the built environment the closer to that other side of things you are and it is that I like.

Referring to other influential factors, another respondent stated; 
When I've been on my own and you get to the top of a mountain somewhere, if it's nice weather and you've really enjoyed it, it is almost a religious experience, being on your own. Nobody else about you and you are part of nature and it's almost a religious experience.

Thus, it was evident from the research that respondents frequently sought solitude, whether being physically on their own or taking a few moments to enjoy their own thoughts and feelings. Moreover, it was also evident that the sense of solitude could be enhanced by physical activity, the repetitiveness of the body's movement helping to shed concerns and open the mind to more enlightened and positive thoughts. Indeed, as already noted and now discussed in the following section, physical activity in the countryside was revealed as a powerful influence on spiritual / emotive experiences.

\section{Physical activity}

It has long been recognised that physical activity undertaken in a specific environment fosters a sense of close engagement with place (Wylie, 2005). More specifically, it has been demonstrated that spiritual experiences arise from gratifying physical activities that focus attention completely on the task, attributed to a state of 'flow' in which 'internal and external worlds are fused into a single stream of being' (Williams \& Harvey, 2001, p.250). Thus, given that the interview respondents were purposefully selected on the basis of, amongst other things, being active tourists in the Lake District, it is not surprising that being physically active in the rural environment was revealed as an important element of their touristic experience. The phrases and words they used to describe the emotional outcomes of their activity in the countryside were: contentment, satisfaction, achievement, joy, restorative, therapeutic, challenging, meditative, stress release, enjoyment, escape, freedom, peaceful and mentally healthy.

Many respondents participated regularly in walking. According to Drury (2008, p. 105), 'across nearly all spiritual traditions and throughout many lands, walking plays a central role in spiritual practice, texts disciplines and customs', and many respondents 
referred implicitly or explicitly to the emotional / spiritual dimension of their walking experiences:

The spirituality thing is something that builds as you go along because you start off and you are still anchored in the built environment and all the hang ups of work and the rest of it but as you go on walking - it's a journey-you gradually get to the point where you feel a lot better. At the end of it you've done a physical journey and a mental journey.

Sometimes I think of walking as a bit like a replacement for going to church because it is the sort of thing that allows you to have space and put things in perspective. Walking puts me in touch with my spiritual side.

For some respondents, spiritual fulfilment arose from the overcoming the challenge of physical activity, from physical achievement. Achievement, for many of the interviewees, was considered essential to the experience or gave more meaning to the experience:

There is the satisfaction of being able to do it, having got there, particularly if it is uphill...the satisfaction of achievement.

I think perhaps it is being high physically...it makes you feel high emotionally and spiritually as well but it is also about achieving because I've had to walk up there as well.

Conversely, for others, positive emotional benefits were achieved without the need to overcome a challenge:

It's never about accomplishing anything when I go walking. It is never really about getting to the top. The feelings for me are probably...peaceful. It definitely refreshes me. 
Thus, the individual experience of emotional or spiritual feelings was determined by individual circumstances, yet it was apparent that the elements of views, challenge and achievement were a common theme in spiritual responses to physical activity.

\section{Sense of place: the Lake District}

As considered in the introduction to this paper, rural tourism is frequently associated with a sense of place; that is, the attraction of the countryside is widely regarded as lying in the attachment that visitors feel towards particular rural places, an attachment that is a function of the physical characteristics of the place, the meanings that individuals attach to it through their behaviours and experiences, and the socially-constructed significance (rurality) of the countryside. A question yet to be addressed in the literature, of course, is the extent to which a rural sense of place may be augmented through the meaning that individual tourists attach to their visits, or superseded by a spiritual dimension to the rural tourism experience - hence the focus of this study. Therefore, the research sought to establish through the interviews whether respondents felt a strong attachment to the Lake District in particular.

Certainly, the respondents all regarded the Lake District as exceptional and described it with fervour and enthusiasm:

I think because it is a unique landscape in England. It's the geography of it, the charming little villages...it's very beautiful, very special and it's very historical. The houses look as if they are growing out of the landscape. The dry stone walls look like sculptures, covered in moss and everything. It just conspires to make itself look almost too good to be true sometimes.

More specifically, the analysis of the interview data revealed several prominent themes relevant to sense of place in the context of the Lake District which were grouped under three broad headings, namely: place, person, and process. Particular elements of these are considered in the following sections as a basis for subsequently discussing the 
extent to which emotional or spiritual fulfilment is a prominent outcome of rural tourism experiences of the Lake District.

\section{i.Place}

According to Wynveen, Kyle \& Sutton (2012, p. 288), 'meanings ascribed to particular places often reflect the physical characteristics of the setting and the social interaction that occurs there'. Throughout the interviews, there was unanimous agreement that the physical environment of the Lake District was a principal factor in respondents' emotional engagement with and attachment to place. For many, it was the balance between nature and human influences that was a powerful influence, although some expressed a connectedness with the natural environment:

I feel as if I am part of something that has happened thousands of years ago... I feel I want to be part of that life and by being on the fells and appreciating how they were formed I'm sharing an experience with them.

More specifically, the naturalness of the Lake District was revealed as a strong incentive for visiting the area, one respondent summarising that being out in the hills and fells that is a far more appealing an attachment than walking through a town or the bricks and mortar that make up a landscape. At the same time, the Lake District was perceived as a place of exceptional scenery and views, no doubt as a result of socially constructed visions of the countryside landscape. For many respondents, the unique scenic qualities of the Lake District contributed substantially to feelings of attachment and a sense of place:

It seems to be the right amount of green, the right amount of orange in the trees, the odd crag just peeking out and it just seems to fit. Everything just seems to fit into place. Just as it should! 
Equally, the built environment was seen to add to the charm of the Lake District, but but this was not of primary interest to some of the respondents, perhaps reflecting their aversion to and/or avoidance of crowds of people, the importance of their activity, their desire to engage with nature.

\section{ii. Person}

Not only is the Lake District a physical landscape; it is also a cultural landscape endowed with historical, literary and artistic meaning (Walton \& Wood, 2013). Thus, it might be assumed that tourists experience a sense of personal attachment to the Lake District through these cultural associations. For most respondents, however, the history of the area was something they had considered at some point but had not given a great deal of thought to. More specifically, a sense of history did not appear to influence most respondents’ emotional involvement with place. Similarly, and perhaps more surprisingly, the Lake District’s strong literary associations were not influential in respondents' motivations to visit and in their experiences:

The feeling that you get when you are in the Lakes and the thing that evokes something intensely personal is quite different than what you get from reading someone else's experiences. You make your own photo by being there!

Indeed, the research confirmed Urry's (1995) claim that literary and artistic associations are not a primary motivator for tourists visiting the Lake District and many visitors are, in fact, often unaware of them. Thus, at a personal level, respondents did not sense a culturally-influenced attachment to the place. Rather, it was again physical engagement with the environment that inspired a feeling of attachment.

\section{iii. Process}

Most respondents revealed a strong emotional attachment to the Lake District, underpinning their continuing visits to the area, arising from what may be described as 
process; that is, the ways in which the Lake District had been and remained instrumental in personal and social activities. For example, many had brought their children on family days out / holidays and, although most now had grown up families, it became apparent that they still enjoyed and cherished both past and current visits together in the Lake District:

It has been bound up with very important relationships in my life. I've walked with $A L$ for forty years... and it is something that has bound us. We've taken the children there and they've grown up doing all these things

Similarly, childhood memories and experiences were revealed as particularly influential in participants' present experiences of the Lake District, many respondents holding strong childhood associations with the area. Consequently, these early experiences and the memories they created appear to play a strong part in respondents' attachment to the Lake District:

My love of the Lakes and the outdoors started from day walks with a church group...from the age of eleven...I was fortunate that I had people who showed me that there is more to life than being in towns...wilderness and beauty.

For many respondents, an important aspect of their experience of the Lake District was a sense of social belonging, or being part of a group or community of fellow walkers people of different backgrounds, various ages and gender - but all like-minded in terms of the activity. Memories had been created through their experiences and these were tied not only to the group members but to the places where the memories were created. Thus, as previously found by Kyle et al. (2004), as social ties to the activity grew along with the importance of the activity, so did respondents' emotional attachment to a particular setting or place. In effect, social interactions, aligned with setting and activity combined to strengthen place bonds, thus confirming the importance of the place social bonding process referred to earlier in this paper (Ramkissoon et al., 2012). 
More generally, from the research it became evident that many respondents were enthralled by the Lake District and had formed strong attachments to the area:

It is my favourite place...its magic. Whenever we go away we always come back and go for a walk in the Lakes.

It is just a natural beauty that you can appreciate and you come away feeling that you have been part of that but you want to get to know it more.

When I am walking in the Lake District I feel like I am walking on my own turf.

In other words, the research revealed that most respondents experienced a sense of place in the Lake District, an attachment to the area that drew them back regularly as tourists. Importantly, however, that sense of place emanated primarily from past and present social connections, such as visiting with family, whilst the area's natural beauty - the physical environment - also remained a dominant pull factor. Conversely, the socially-constructed meaning of the Lake District as a significant literary / artistic landscape was not influential in respondents' touristic experiences whilst, of particular relevance to this paper, the notion of rurality more generally was not a factor discussed by respondents. That is, although particular characteristics of the rural environment, such as scenic quality and tranquillity, were identified as attractions (and potential sources of emotional / spiritual feelings), the broader rurality of the Lake District was not a significant factor in respondents’ motivations or experiences. What conclusions, then, can be drawn from this research with regards to an emotional or spiritual dimension to the rural tourism experience?

\section{Conclusion: sense of place or spiritual experience?}

As established in the introduction, the purpose of this paper was to identify and explore the potential emotional or spiritual dimension that might help form rural tourism experiences. It sought to consider whether, as widely suggested, rural tourism is framed by a socially- 
constructed understanding of the countryside, or 'rurality', that determined the nature of rural tourists' experiences, or whether such experiences involved a deeper, emotional dimension. A number of clear conclusions emerged from the research.

First, as noted above, rural tourists do express an attachment to the countryside, a sense of belonging to particular places (in this case, the Lake District), though one primarily determined by past and present social experiences, or a process of place social bonding (Ramkissoon et al., 2012), rather than a broader culturally-defined understanding. At the same time, many respondents related their attachment to the Lake District to its scenic qualities, reflecting Stedman’s (2003) argument that the physical environment may be the dominant factor in establishing a sense of place. Thus, absent from the respondents' understanding of their attachment to the Lake District is the third element of place, namely, its constructed cultural meaning. This suggests not only that the principal reason for visiting the area, apart from the practicalities of activity opportunities and proximity, is a combination of scenic quality, familiarity and significant social experiences associated with the place, but also that the relevance of the concept of rurality, at least as a driver of rural tourism, demands further enquiry.

Second, it is clearly evident from the research that participating in specific forms of rural tourism elicits a deeper, emotional experience. Such experiences may be termed or recognised as 'spiritual'; equally, they may be described as 'emotional'. Indeed, in this research, the respondents used similar words and phrases to describe their responses to specific elements of the tourism experience, such as the place, the weather or the activity, the only distinction being whether they considered themselves to be religious, spiritual or nonreligious/spiritual. In other words, all respondents recognised that there exists a deeper, more meaningful dimension to their touristic experience of the Lake District, their understanding of this being determined by their predisposition or openness to religious or spiritual beliefs. Thus, tourism to the Lake District elicits an emotional response; whether or not this is defined as spiritual is person-dependent, suggesting that the common assertion that tourism more generally is a secular scared experience demands further interrogation.

Third, such emotional experiences emerge from varying combinations of being in the physical environment and engaging with it through some form of physical activity. For some respondents, being in and gazing upon the landscape and nature, experiencing its tangible and intrinsic qualities, was sufficient to elicit an emotional response whereas, for others, it was 
the physical activity and, perhaps, achievement, that was dominant. Either way, and in the context of this paper at least, the research suggests that being in and engaging with the landscape - effectively becoming part of it - is fundamental to emotional responses; conversely, more passive and 'urban' forms of rural tourism are less likely to elicit emotional experiences amongst visitors.

Fourth, the relationship between sense of place and spiritual / emotional experiences remains unclear. That is, it was not possible to conclude from the interviews whether the emotional / spiritual experiences described by the respondents occurred independently from or built upon the foundations of their expressed attachment to the Lake District, whether sense of place is a prerequisite to deeper, emotional experiences. Certainly, some respondents spoke of their emotional experiences in other rural areas, suggesting that the factors identified as stimulating such experiences were, in a sense, transferable to locations other than the Lake District. Nevertheless, the respondents' description of their experiences in the Lake District point to an intertwining of place attachment and emotional / spiritual experiences which, if not dependent upon, are enhanced by a sense of place.

Fifth, in terms of rural destination marketing and management, it is evident from this research that sense of place is a significant determinant of demand for tourism in the Lake District and, hence, promoting sense of place as a form of branding may strengthen customer loyalty (or encourage repeat visits). Indeed, a 'Sense of Place Toolkit' is now available for tourism businesses in the Lake District to 'provide visitors with a greater understanding of the [area’s] rich and deep heritage and traditions' (Cumbria Tourism, 2013). However, the effectiveness of this may be limited, given that, as revealed by this research and others, individuals tend to assign their own values and perceptions to a place based on personal experiences and expectations (Baerenholdt, Haldrup, Larsen \& Urry, 2004). Thus, efforts may be better directed towards maintaining and promoting the natural qualities of the countryside as a place for active pursuits and social bonding.

Finally, it must be accepted that it is not possible to isolate the emotional responses of rural tourists as explored in this paper from their lives more generally. That is, human existence reflects a series of interconnected events and, hence, spiritual or emotional experiences of touristic encounters with the countryside may in fact be responses to influences or events beyond the rural tourism context (Heintzman, 2010). At the same time, the specificity of this research, focusing as it does on active rural tourists in the Lake District, 
suggests that further studies may be necessary amongst different groups of tourists and / or in different locations. Nevertheless, as one of very few empirical studies of the alleged relationship between tourism and spirituality, it verifies that rural tourism may, in certain circumstances, arouse emotional responses amongst tourists, responses which, depending on the individual concerned, may be termed spiritual.

\section{References}

Aitchison, C., MacLeod, N. and Shaw, S. (2000). Leisure and tourism landscapes: Social and cultural geographies. London: Routledge.

Allcock, B. (1988). Tourism as a sacred journey. Loisir et Société, 11(1), 33-48.

Ashley, P. (2007). Toward an understanding and definition of wilderness spirituality. Australian Geographer, 38(1), 53-69.

Baerenholdt, J., Haldrup, M., Larsen, J. \& Urry, J. (2004). Performing tourist places. Farnham: Ashgate.

Barsham, D. \& Hitchcock, M. (2013). Prophets of nature: Romantic ideas of nature and their continuing relevance for tourism today. In A. Holden \& D. Fennell (Eds.) The Routledge handbook of tourism and the environment (pp.54-64). Abingdon: Routledge.

Bremer, T. (2006). Sacred spaces and tourist places. In D.Timothy \& D. Olsen (Eds.) Tourism, religion and spiritual journeys (pp. 25-35). Abingdon: Routledge.

Bull, A. (2006). Is a trip to the seaside a spiritual journey? Unpublished paper presented at the Tourism: The Spiritual Dimension Conference. UK: University of Lincoln.

Bunce, M. (1994). The countryside ideal: Anglo-American images of landscape. London, Routledge. 
Burls, A. (2007). People and green spaces: promoting public health and mental well-being through ecotherapy. Journal of Public Mental Health, 6(3), 24-39.

Burchardt, J. (2002). Paradise lost: Rural idyll and social change since 1800. London, I.B. Tauris.

Cain, T. (2013). The importance of the aesthetic. In A. Holden \& D. Fennell (Eds.), The Routledge handbook of tourism and the environment (pp. 65-74). Abingdon: Routledge.

Casey, E. (1993) Getting back into place: Toward a renewed understanding of the placeworld. Bloomington: Indiana University Press.

Cloke, P. (2006) Conceptualizing rurality. In P. Cloke, T. Marsden \& P. Mooney (Eds.), Handbook of rural studies (pp. 18-28). London: Sage Publications.

Cloke, P. and Little, J. (Eds.) (1997). Contested countryside cultures. London: Routledge.

Coble, T., Selin, S. \& Erickson, B. (2003) Hiking alone: Understanding fear, negotiation strategies and leisure experience. Journal of Leisure Research, 35(1), 1-22.

Cresswell, T. (2004). Place. A short introduction. Oxford: Blackwell Publishing.

Crystal, L. (1995). The SOS - A spiritual opportunity spectrum: Theory and implications of spirit of place for ecosystem management. Moscow, Idaho: University of Idaho.

Cumbria Tourism (2013). The Lake District, Cumbria sense of place toolkit. Available at: http://www.cumbriatourism.org/marketing/sense-of-place.aspx (accessed 19 December 2013)

Dann, G. (1977). Anomie, ego-enhancement and tourism. Annals of Tourism Research, 4(4), 184-194.

Darby, W. (2000). Landscape and identity: Geographies of nation and class in England. Oxford: Berg.

Darker, C., Larkin, M. \& French, D. (2007). An exploration of walking behaviour: An interpretative phenomenological approach. Social Science \& Medicine, 65(10), 21722183. 
Denyer, S. (2013). The Lake District landscape: Cultural or natural? In J. Walton \& J. Wood (Eds.) The making of a cultural landscape: the English Lake District as a tourist destination, 1750-2010 (pp. 2-29). Farnham: Ashgate.

de Vries, H. (Ed.) (2008). Religion: Beyond a concept. Bronx, NY: Fordham University Press.

de Vulpian, A. (2008). Towards the third modernity: How ordinary people are transforming the world. Axminister: Triarchy Press Ltd.

Digance, J. (2006). Religious and secular pilgrimages: Journeys redolent with meaning. In D. Timothy \& D. Olsen (Eds.) Tourism, religion and spiritual journeys (pp.36-48). Abingdon: Routledge.

Driver, B., Dustin, D., Baltic, T., Elsner, G. \& Peterson, G. (Eds.) (1996). Nature and the human spirit: Toward an expanded land management ethic. State College, PA: Venture Publishing.

Drury, P. (2008). Sustainability and spirituality in Cascadia.. In D. Todd (Ed.) Cascadia: The elusive Utopia - Exploring the spirit of the Pacific Northwest (pp. 143-156). Vancouver, CA: Ronsdale Press.

Elkins, D., Hedstrom, L., Hughes, L., Leaf, J. \& Saunders, C. (1988) Toward a humanistic phenomenological spirituality: Definition, description and measurement. Journal of Humanistic Psychology, 28(4), 5-18.

Flanagan, K. and Jupp, P. (Eds.) (2007). A sociology of spirituality. Farnham: Ashgate.

Fredrickson, L. \& Anderson, D. (1999). A qualitative exploration of the wilderness experience as a source of spiritual inspiration. Journal of Environmental Psychology, 19(1), 21-29.

Fredrickson, L. and Kerr, W. (1998). Spiritual values: Can they be incorporated into forest management and planning? In H. Vogelsong (Ed.) Proceedings of the 1998 Northeastern Recreation Research Symposium (pp.239-245) Newton Square, PA: US Department of Agriculture.

Gieryn, T. (2000). A space for place in sociology. Annual Review of Sociology, 26(1), 463496. 
Graburn, N. (1989). Tourism: The sacred journey. In V. Smith (Ed.) Hosts and guests: The anthropology of tourism (pp.21-36). Philadelphia: University of Pennsylvania Press.

Greider, T. \& Garkovich, L. (1994) Landscapes: The social construction of nature and the environment. Rural Sociology, 59(1), 1-24.

Halfacree, K. H. (1993). Locality and social representation: Space, discourse and alternative definitions of the rural. Journal of Rural Studies, 9(1), 23-37.

Hammitt, W., Backlund, E., \& Bixler, R. (2006). Place bonding for recreational places: Conceptual and empirical development. Leisure Studies, 25(1), 17-41.

Haq, F. \& Jackson, J. (2006). The recognition of marketing of spiritual tourism as a significant new area in leisure travel. Unpublished paper presented at the Tourism: The Spiritual Dimension Conference. UK: University of Lincoln.

Harrison, C. (1991). Countryside recreation in a changing society. London: TMS Partnership Ltd.

Heelas, P. \& Woodhead, L. (2005). The spiritual revolution: Why religion is giving way to spirituality. Oxford: Blackwell Publishing.

Heintzman, P. (2007). Men’s wilderness experience and spirituality: Further explorations. Proceedings of the 2007 Northeastern Recreation Research Symposium. Newton Square, PA, US: Department of Agriculture, Forest Service.

Heintzman, P. (2010). Nature-based recreation and spirituality: A complex relationship. Leisure Sciences, 32(1), 72-89.

Houtman, D. \& Aupers, S. (2007). The spiritual turn and the decline of tradition: The spread of post-Christian spirituality in 14 western countries, 1981-2000. Journal for the Scientific Study of Religion, 46(3), 305-320.

Horton, J. (2008). Producing Postman Pat: The popular cultural construction of idyllic rurality. Journal of Rural Studies, 24(4), 389-398.

Jorgensen, B. \& Stedman, R. (2001). Sense of place as an attitude: Lakeshore owners' attitude to their properties. Journal of Environmental Psychology, 21(3), 233-248. 
Kaplan, S. (1995). The restorative benefits of nature: Towards an integrative framework. Journal of Environmental Psychology, 15(3), 169-182.

Kastenholz, E. \& Lima, J. (2011). The integral rural tourism experience from the tourist's point of view: A qualitative analysis of its nature and meaning. Tourism and Management Studies, 7, 62-74.

Klenke, K. (2008). Qualitative research in the study of leadership. Bingley: Emerald Group Publishing Ltd.

Korpela, K. \& Hartig, T. (1996). Restorative qualities of favourite places. Journal of Environmental Psychology, 16(3), 221-233.

Kyle, G., Bricker, K., Graefe, A. \& Wickham, T. (2004. An examination of recreationists' relationships with activities and settings. Leisure Sciences, 26(2), 123-142.

Kyle, G. \& Chick, G. (2007). The social construction of the sense of place. Leisure Sciences, 29(3), 209-225.

Laing, J. \& Crouch, G. (2009). Lone wolves? Isolation and solitude within the frontier travel experience. Geografiska Annaler Series B: Human Geography, 91(4), 325-342.

Lambert, Y. (2004). A turning point in religious evolution in Europe. Journal of Contemporary Religion, 19(1), 29-45.

Lane, B. (1994) What is rural tourism? Journal of Sustainable Tourism, 2(1\&2), 7-21.

Lane, B. (2009) Rural tourism: An overview. In T. Jamal \& M. Robinson (Eds.) The Sage handbook of tourism studies (pp. 355-372). London: Sage Publications.

Little, J. \& Austin, P. (1996). Women and the rural Idyll. Journal of Rural Studies, 12(2), 101-111.

Little, D. \& Schmidt, C. (2006). Self, wonder and God! The spiritual dimensions of travel experiences. Tourism: An International Interdisciplinary Journal, 54(2), 107 - 116.

Mannell, R. (1996). Approaches in the social and behavioral sciences to the systematic study of hard-to-define human values and experiences. In B. Driver, D. Dustin, T. Baltic, G. Elsner \& G. Peterson (eds.) Nature and the human spirit: Toward an expanded land management ethic (pp. 404-416). State College, PA: Ventura Publishing. 
Manzo, L. (2003). Beyond house and heaven: Toward a revisioning of emotional relationships with places. Journal of Environmental Psychology, 23(1), 47-61.

Manzo, L. (2005). For better or worse: Exploring multiple dimensions of place meaning. Journal of Environmental Psychology, 25(1), 67-86.

Mason, M. (2000) Spirituality: What on earth is it? Paper presented at the International Conference of Children's Spirituality, Roehampton Institute. Available on: https://humanism.org.uk/wp-content/.../SpiritualitywhatonEarthisit.pdf (Accessed 19 June 2014).

Montes, S. (1996). Use of natural settings to promote, maintain and restore human health. In: B. Driver, D. Dustin, T. Baltic, G. Elsner \& G. Peterson, G. (Eds.) Nature and the human spirit: Toward an expanded land management ethic (pp.105-124). State College, PA: Ventura Publishing.

Morgan, P. (2009). Towards a developmental theory of place attachment. Journal of Environmental Psychology, 30(1), 11-22.

Nash, D. (1996). Anthropology of tourism. Oxford: Pergamon

Newby, H. (1985). Green and pleasant land? Social change in rural England. London: Wildwood House.

OED (2014) Oxford English Dictionary (Online). http://www.oed.com (Accessed 19 June 2014).

O’Neill, C. \& Walton, J. (2004). Tourism and the Lake District: Social and cultural histories. In J. Hind \& D. Mitchell (Eds.), Sustainable tourism in the English Lake District (pp. 19-47). Sunderland: Business Education Publishers Limited.

Pargament, K. (1999). The psychology of religion and spirituality? Yes and no. International Journal for the Psychology of Religion, 9(1), 3-16.

Patton, M. (1990). Qualitative evaluation methods. Beverley Hills, CA: Sage Publications.

Ramkissoon, H., Weiler, B. \& Smith, L. (2012). Place attachment and pro-environmental behaviour in national parks: The development of a conceptual framework. Journal of Sustainable Tourism, 20(2), 257-276. 
Relph, E. (1976). Place and placelessness. London, Pion.

Roberts, L. \& Hall, D. (2001). Rural tourism and recreation: Principles to practice. Wallingford: CABI.

Seaton, T. (2013). Tourism and romantic myths of nature. In A. Holden \& D. Fennell (Eds.) The Routledge handbook of tourism and the environment (pp. 94-114). Abingdon: Routledge.

Sharpley, R. (2007). Tourism and leisure in the countryside, $5^{\text {th }}$ edn. Huntingdon: Elm Publications.

Sharpley, R. \& Jepson, D. (2011). Rural tourism: A spiritual experience? Annals of Tourism Research, 38(1), 52-71.

Short, J. (1991) Imagined country: Environment, culture and society. London: Routledge.

Stark, R., Hamberg, E., \& Miller, A. (2005). Exploring spirituality and unchurched

religions in America, Sweden and Japan. Journal of Contemporary Religion, 20(1), 3-23.

Stedman, R. (2003). Is it really just a social construction? The contribution of the physical environment to sense of place. Society \& Natural Resources, 16(8), 671-685.

Stringer, L. \& McAvoy, L. (1992) The need for something different: Spirituality and the wilderness adventure. The Journal of Experiential Education, 15(1), 13-21.

Swatton, A. \& Potter, T. (1998) The personal growth of outstanding canoeists resulting from extended solo canoe expeditions. Pathways: The Ontario Journal of Outdoor Education, 9(6), 13-16.

Teasedale, W. (1999). The mystic heart. Novato, CA: New World Library.

Theos (2013). The spirit of things unseen: Belief in post-religious Britain. London: Theos.

Timothy, D. (2013). Religious views of the environment: Sanctification of nature and implications for tourism. In A. Holden \& D. Fennell (Eds.) The Routledge handbook of tourism and the Environment (pp.31-42). Abingdon: Routledge.

Timothy, D. \& Olsen, D. (Eds.) (2006). Tourism, religion and spiritual journeys. Abingdon: Routledge. 
Tuan, Y. (1974). Topophilia: A study of environmental perceptions, attitudes and values.

New York: Columbia University Press.

Tuan, Y. (1977). Space and place: The perspective of experience. Minneapolis: University of Minnesota.

Urry, J. (1995). Consuming places. London: Routledge.

Walton, J. \& Wood, J. (Eds.) (2013). The making of a cultural landscape: The English Lake District as a tourist destination, 1750-2010. Farnham: Ashgate.

Weinberg, D. (2002). Qualitative research methods. Oxford: Wiley-Blackwell Ltd.

Williams, K. \& Harvey, D. (2001). Transcendent experience in forest environments. Journal of Environmental Psychology, 21(3), 249-260.

Woods, M. (2011) Rural. London: Routledge.

Wuthnow, R. (1998) After heaven: Spirituality in America since the 1950s. Berkeley: University of California Press.

Wylie, J. (2005). A single day's walking: Narrating self and landscape on the South West Coast Path. Transactions of the Institute of British Geographers, 30(2), 234-247.

Wynveen, C., Kyle, G. and Sutton, S. (2012). Natural area visitors' place meaning and place attachment ascribed to a marine setting. Journal of Environmental Psychology, 32(4), 287-296.

Zinnbauer, B., Pargament, K., Cole, B., Rye, M., Butler, E., Belavich, T., Hipp, K., Scott, A. \& Kadar, J. (1997). Religion and spirituality: Unfuzzying the fuzzy. Journal for the Scientific Study of Religion, 36(4), 549-564.

\footnotetext{
'European romanticism emerged in the mid to late eighteenth century, with its full development taking place in the period 1800-1850. North American romanticism began post 1820, with Latin America following from the 1830 s.
} 